OPEN ACCESS

Edited by:

Peter Mullany,

University College London, UK

Reviewed by:

D. Ipek Kurtboke,

University of the Sunshine Coast,

Australia

Victor Krylov,

I.I.Mechikov Institute for Vaccines and Sera, Russia

*Correspondence:

Marina Goderdzishvil

mgoderdzishvili@pha.ge

Specialty section: This article was submitted to Antimicrobials, Resistance

and Chemotherapy,

a section of the journal

Frontiers in Microbiology

Received: 11 August 2016 Accepted: 22 September 2016 Published: 04 October 2016

Citation:

Kusradze I, Karumidze N, Rigvava S, Dvalidze T, Katsitadze M, Amiranashvili I and Goderdzishvili $M$ (2016) Characterization and Testing

the Efficiency of Acinetobacter baumannii Phage vB-GEC_Ab-M-G7

as an Antibacterial Agent.

Front. Microbiol. 7:1590.

doi: 10.3389/fmicb.2016.01590

\section{Characterization and Testing the Efficiency of Acinetobacter baumannii Phage vB-GEC_Ab-M-G7 as an Antibacterial Agent}

\author{
la Kusradze', Natia Karumidze1, Sophio Rigvava1, Teona Dvalidze ${ }^{1,2}$, \\ Malkhaz Katsitadze ${ }^{1}$, Irakli Amiranashvili3 and Marina Goderdzishvili ${ }^{1 *}$
}

${ }^{1}$ G. Eliava Institute of Bacteriophages, Microbiology and Virology, Tbilisi, Georgia, ${ }^{2}$ Ivane Javakhishvili Tbilisi State University, Tbilisi, Georgia, ${ }^{3}$ Institute of Medical Research, Ilia State University, Tbilisi, Georgia

Acinetobacter baumannii is a gram-negative, non-motile bacterium that, due to its multidrug resistance, has become a major nosocomial pathogen. The increasing number of multidrug resistant (MDR) strains has renewed interest in phage therapy. The aim of our study was to assess the effectiveness of phage administration in Acinetobacter baumannii wound infections in an animal model to demonstrate phage therapy as non-toxic, safe and alternative antibacterial remedy. Using classical methods for the study of bacteriophage properties, we characterized phage vB-GEC_Ab-M-G7 as a dsDNA myovirus with a $90 \mathrm{~kb}$ genome size. Important characteristics of $v B$ GEC_Ab-M-G7include a short latent period and large burst size, wide host range, resistance to chloroform and thermal and $\mathrm{pH}$ stability. In a rat wound model, phage application effectively decreased the number of bacteria isolated from the wounds of successfully treated animals. This study highlights the effectiveness of the phage therapy and provides further insight into treating infections caused by MDR strains using phage administration.

Keywords: Acinetobacter baumannii, bacteriophage, phage therapy, animal model, wound infection

\section{INTRODUCTION}

Acinetobacter baumannii is a gram-negative, non-motile bacterium that has become a major nosocomial pathogen due to its multidrug resistance. A. baumanni strains have been isolated which are resistant to almost all antibiotics, including a high prevalence of resistance to carbapenems which has been reported worldwide since the 1990's (Kempf and Rolain, 2012; Ahmed et al., 2016; Nowak and Paluchowska, 2016). Most of the strains are still sensitive in vitro to colistin, an antibiotic which was considered toxic for a long time (Montero et al., 2004). Recent studies suggest it can actually be used as an efficient antimicrobial agent (Michalopoulos and Falagas, 2011). But colistin resistant A. baumannii strains have already been reported (Lopez-Rojas et al., 2011; Kempf and Rolain, 2012; Gupta et al., 2016; Yilmaz et al., 2016). Currently there is no remedy to effectively remove A. baumannii from the hospital environment, as this microbe is resistant to dehydration, chemical sanitizers and detergents (Yang et al., 2010). As a result, the risk of A. baumannii nosocomial infection is increasing.

The worldwide spread of MDR strains of a number of different pathogens has renewed interest in bacteriophage therapy. Bacteriophages are viruses which infect and lyse bacteria. Lytic phages for 
the treatment of infections were first introduced by Felix d'Herelle in 1920 (Matsuzaki et al., 2005). Due to their observed efficacy and recognized specificity, phages have been used as a treatment modality in the Formers Soviet Union and Eastern Europe, especially in Georgia, for decades; much successful work was also carried out in France and elsewhere (Matsuzaki et al., 2005; Sulakvelidze, 2005; Kutter et al., 2010).

The study of phage therapy in animal models is an essential bridge between in vitro and clinical studies. Mice with artificial burns, pneumonia, pulmonary infections with various microbes (Pseudomonas spp., Staphylococcuss spp., Enterococcuss spp., Klebsiella pneumoniae, Escherichia coli) were successfully treated with phages (Biswas et al., 2002; Chibani-Chennoufi et al., 2004; Vinodkumar et al., 2005; McVay et al., 2007; Debarbieux et al., 2010; Morello et al., 2011). Although several A. baumannii phages have been isolated and characterized in terms of potential therapeutic application (Soothill, 1992; Yang et al., 2010; Popova et al., 2012), a very few in vivo trials for $A$. baumannii phages have been reported: Wang et al. (2016), showed successfully use of phage intranasal application for treatment pneumonia on mice model. All mice survived after intranasal application of phages published by Jeon et al. (2016) as well. Uncontrolled diabetic rats were used for infected wound modeling for study phage therapy effectiveness by Shivaswamy et al. (2015), where ones more was demonstrated A. baumannii phage prospects for treatment of MDR bacteria caused infections. Several studies done in Georgia at Eliava Institute of BMV highlight phage therapy advantages and effectiveness, as well (Kutateladze and Adamia, 2008, 2010). Furthermore, a range of phages targeting the organism in question are required to successfully develop a phage therapy approach. In our study we have characterized a promising new lytic $A$. baumannii bacteriophage $v B \_A b-M-$ $G 7$ and report its potential in phage therapy on a rat wound model, using both its original and a French clinical strain of A. baumannii.

\section{MATERIALS AND METHODS}

\section{Bacterial Strains, Identification}

Clinical isolates of Acinetobacter baumannii G7 and T-10 were used in this study. A. baumannii strains $G 7$-isolated in Georgia from an injured soldier during the GeorgianRussian War in 2008 as previously described (Kusradze et al., 2011), was used for isolation and concentration of the reported phage. Strain T-10 was isolated from a patient in the hospital de la Timone, Marseille, France. Bacteria were grown at $37^{\circ} \mathrm{C}$ in Brain Heart Infusion broth and agar, and in Herellea Agar (Jawad et al., 1994). Matrixassisted Laser Desorption Time-of-Flight Mass Spectrometry (MALDI-TOF MS) (Autoflex, Bruker Daltonics) with the flex control software (Bruker Daltonics) was used for identification these strains. A score value $>1.9$ is considered adequate for identification at the species level (Seng et al., 2009).

\section{Phage Isolation, Concentration, Purification}

Bacteriophage was isolated from sewage water. After overnight incubation of the sewage samples with microbial culture in Brain Heart Infusion Broth (BHIB) at $37^{\circ} \mathrm{C}$, samples were centrifuged at $5000 \mathrm{~g}$ for $20 \mathrm{~min}$ and filtrated and the supernatant was checked for phages by a standard spot test: overnight host strain (18-24 h.) diluted in BHIB $10^{8} \mathrm{cfu} \mathrm{ml}^{-1}$ were streaked onto a Petri plate with $1.5 \%$ agar. After drying of the lines (15$20 \mathrm{~min}$ ), $0.05 \mathrm{ml}$ of each supernatant was spotted onto each line. Plates were incubated at $37^{\circ} \mathrm{C}$ for $18 \mathrm{~h}$. After incubation, the appearance of lysis zones on the bacterial lines shows the presence of phages (Garbe et al., 2010; Karumidze et al., 2013). Phage concentration and plaque morphology was determined by serial dilution of the phage lysate, $1 \mathrm{ml}$ serial diluted phage and $0,1 \mathrm{ml}$ indicator bacteria was added to $4.5 \mathrm{ml} 46^{\circ} \mathrm{C}$ $0.7 \%$ soft-agar and poured onto the $1,5 \%$ bottom agar on Petri dishes. After $30 \mathrm{~min}$ the plate was incubated at $37^{\circ} \mathrm{C}$. The results were counted after 18-24 h. Plaque Purification of bacteriophage was repeated 15-20 times. Purified phage was amplified and titer in the filtrate was assessed by using the doubleagar layer method (Lin et al., 2010). The phage lysate was stored at $4^{\circ} \mathrm{C}$.

\section{Phage Host Range Spectrum, Single Step Growth Curve, Adsorption Rate}

The phage host range spectrum was determined on 200 A. baumannii strains (Eliava Collection) using a standard spot test protocol (Garbe et al., 2010; Karumidze et al., 2013). To determine phage growth characteristics (latent period, burst size), experiments were carried out according to the previously described (Drulis-Kawa et al., 2011; Rigvava et al., 2013), with some modifications. A. baumannii strain was grown in $10 \mathrm{ml}$ BHIB until the exponential growth phase, $0,1 \mathrm{ml}$ phage with titer $10^{8} \mathrm{pfu} \mathrm{ml}^{-1}$ was added at a multiplicity of infection (MOI) of 0.1 . Samples were taken periodically for the determination of phage growth parameters.

To calculate the phage adsorption rate, $1 \mathrm{ml}$ bacterial suspension $\left(10^{7} \mathrm{cfu} \mathrm{ml}{ }^{-1}\right)$ and $1 \mathrm{ml}$ phage lysate $\left(10^{8} \mathrm{pfu} \mathrm{ml}^{-1}\right)$ were mixed and incubated at $37^{\circ} \mathrm{C} .0 .1 \mathrm{ml}$ samples were taken at $0,5,7,10^{\prime}, 15^{\prime}$, and $20^{\prime} \mathrm{min}$ and added to $9,9 \mathrm{ml}$ BHIB and $0,4 \mathrm{ml}$ chloroform. Samples were mixed well and plated using the double agar-layer method to determine the amount of unabsorbed phages.

\section{$\mathrm{pH}$, Chloroform and Thermal Stability Tests}

The phage preparation $\left(1 \times 10^{10} \mathrm{pfu} \mathrm{m}^{-1}\right)$ was incubated at 37,50 , and $70^{\circ} \mathrm{C}$ for $24 \mathrm{~h}$. From chloroform stability tests, $1 \mathrm{ml}$ $\left(1 \times 10^{10} \mathrm{pfu} \mathrm{ml} \mathrm{m}^{-1}\right)$ bacteriophage was mixed with $0.4 \mathrm{ml}$ chloroform and incubated for $24 \mathrm{~h}$ at room temperature. For $\mathrm{pH}$ stability studies, phage at $1 \times 10^{10} \mathrm{pfu} \mathrm{ml}^{-1}$ was incubated at

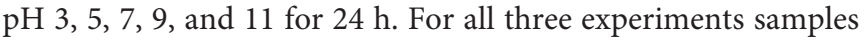
were taken at 5 and $24 \mathrm{~h}$ and the phage titer was determined using the double-agar-layer method. BHI broth and BHI agar were used. 


\section{Electron Microscopy}

Phage morphology was determined by transmission electron microscopy as following: a $5 \mu \mathrm{l}$ sample was placed onto a fresh glow discharged pioloform coated grid; the excess sample was removed and the grid was washed using $2 \times$ DDW (Double Distilled Water); 2 drops of $1 \%$ uranyl acetate were added, the excess was immediately removed and the grid was allowed to air dry. Samples were viewed on a JEOL JEM 1400 TEM with an accelerating voltage of $80 \mathrm{kV}$. Images were captured using a Megaview III digital camera with iTEM software.

\section{Phage DNA Isolation, Restriction Endonuclease Analysis, PFGE}

Before phage DNA isolation, the phage lysate was treated with DNAse and RNAse to remove residual bacterial debris. Standard PCR (Polymerase chain reaction) was used to verify the purity of the phage lysate with universal primers (536F CAGCAGCCGCGGTAATAC, Rp2 ACGGCTACCTTGTTACGACTT) targeting the 16S rRNA gene as previously described (Bittar et al., 2008). Phage DNA isolation was performed by using High Pure Viral Nucleic Acid Qiagen Kit (QIAGEN, Courtaboeuf, France) according to the manufacturer's instructions. For digestion of phage DNA 8 different restriction endonucleases (BamHI, EcoR I, EcoRV, HindIII, HincII, PstI, DpnI, SpeI) were used according to the instructions provided by manufacturer. For separation of the DNA fragments, electrophoresis was done using $0.8 \%$ agarose gel. Restriction digestions were repeated three times. Pulsed-field gel electrophoresis was performed as described in Lin et al. (2010) for determination of the phage DNA size.

\section{Preparation for Animal Wound Model}

Animal experiments were done according to the Animal Rights Committee in Georgia, which fully recognizes the Universal Declaration of Animal Rights.

A total of 30 adult rats weighing 200-300 g were used in this study. Experimental wounds were done as following: each rat was anesthetized and secured to the operating table. After being shaved, the skin was cleaned in aseptic conditions with a $5 \%$ iodine solution and a dorsal full-thickness $1.5 \times 1.5 \mathrm{~cm}$ surgical wound was administered. Interrupted stitches were used to secure a plastic cover to avoid contamination, as well as for procedures which were performed on the animals daily.

Acinetobacter baumannii T-10 and G7 were used for infection and phage vB-GEC_Ab-M-G7was applied as a therapeutic remedy. A. baumannii $G 7$ was the original host for phage $v B$ GEC_Ab-M-G7, titer on this strain was $1 \times 10^{10} \mathrm{pfu} \mathrm{ml}^{-1}$. A. baumannii $T-10$ was chosen randomly from the strains sensitive to phage $v B-G E C \_A b-M-G 7$, phage titer on this strain was $2 \times 10^{8} \mathrm{pfu} \mathrm{m}^{-1}$. Phage was diluted to receive $5 \times 10^{7} \mathrm{pfu}$ $\mathrm{ml}^{-1}$.

\section{Experimental Animal Wound Model}

The 30 rats with experimental wounds were divided randomly into six groups, each containing five rats. Group I was aseptic wound modeling - no bacteria were added, no phage. Group
II tested phage therapy of the aseptic wound (therapeutic dose) with $1 \mathrm{ml}$ phage application $\left(5 \times 10^{7} \mathrm{pfu} \mathrm{m}^{-1}\right)$, no bacteria were added. Group III - infected wound modeling, $1 \mathrm{ml}$ of Acinetobacter baumannii T-10 $5 \times 10^{8} \mathrm{cfu} \mathrm{ml}^{-1}$ was applied, no phage were added. Group IV tested phage therapy of the wound infected with $1 \mathrm{ml}$ of $A$. baumannii T-10 $\left(5 \times 10^{8} \mathrm{cfu}\right.$ $\left.\mathrm{ml}^{-1}\right), 1 \mathrm{ml}$ of phage $\left(5 \times 10^{7} \mathrm{pfu} \mathrm{m} l^{-1}\right)$ were applied $12 \mathrm{~h}$ after infection. Group V - infected wound modeling, infected with $1 \mathrm{ml}$ of Acinetobacter baumannii G7 $\left(5 \times 10^{8} \mathrm{cfu} \mathrm{ml}^{-1}\right)$, no phage were added. Group VI -phage therapy of the infected wound ( $1 \mathrm{ml}$ of A. baumannii G7 $5 \times 10^{8} \mathrm{cfu} \mathrm{m}^{-1}$ ) with $1 \mathrm{ml}$ phage $\left(5 \times 10^{7} \mathrm{pfu} \mathrm{ml}^{-1}\right)$ applied after $12 \mathrm{~h}$ from infection. Additional, phage $v B$-GEC_Ab-M-G7 (for groups II, IV, and VI) were added on the wounds every $24 \mathrm{~h}$ for 6 days. Samples were taken before phage application at time points 0' (12'), 24', 48', 72', and 144' hours using a sterile swab. $4.5 \mathrm{ml}$ of BHI broth was added to the swab tube and was first titered for bacterial count and then was filtered $(0.22 \mu \mathrm{m})$ and titered for phage, according to previously stated methods. The bacterial titer was determined using Herellea agar, to avoid contamination. At the end of the experiment, every animal was euthanized in accordance with the law of animal rights.

\section{RESULTS}

\section{Bacterial Strains}

Microbial strains T-10 and G7 were identified as A. baumannii using MALDI-TOF MS, with score of 2.224 and 2.272 respectively.

\section{Phage Properties}

Phage $v B$-GEC_Ab-M-G7was isolated from sewage using A. baumannii $G 7$ as the host. Using phage purification methods, concentration and titration, a pure, high titer $\left(10^{10} \mathrm{pfu} \mathrm{ml}^{-1}\right)$ stock of A. baumannii phage was obtained, which had small plaque morphology on Petri dishes using the double-agar-layer method. The study of phage morphology by transmission electron microscopy showed that the phage has an icosahedral head, about $100 \mathrm{~nm}$ in diameter and a $120 \mathrm{~nm}$ long contractile tail, thus belongs to Myoviridae (Matsuzaki et al., 2005) (Figure 1). It was named $v B-G E C \_A b-M-G 7$ (phage phi G7) according to the scheme for the nomenclature of viruses of bacteria (Kropinski et al., 2009).

Host range spectrum studied on $200 \mathrm{~A}$. baumannii strains showed that phage $v B$-GEC_Ab-M-G7was able to infect $68 \%$ of the A. baumannii strains. The latent period of phage phi G7 was $20 \mathrm{~min}$ and the burst size was $120 \mathrm{pfu}$ per infected cell. Most phages (91.1\%) were adsorbed within 7 min (Figure 2).

Thermal stability experiments showed that phage retained $100 \%$ activity after incubation at $37^{\circ} \mathrm{C}$ and almost $90 \%$ of phages were viable after a $24 \mathrm{~h}$ incubation at $50^{\circ} \mathrm{C}$ (Figure 3). However, after $24 \mathrm{~h}$ at $70^{\circ} \mathrm{C}$ no active phages were found. Phage phi G7 was stable after $24 \mathrm{~h}$ of chloroform treatment and over a $\mathrm{pH}$ range of 3-11 for $5 \mathrm{~h}$; by $24 \mathrm{~h}$ the phage titer was reduced to $10^{3} \mathrm{pfu}$ $\mathrm{ml}^{-1}$ at $\mathrm{pH} \mathrm{3}$, but it remained unaffected within the $\mathrm{pH}$ range 5-11(Figure 3). 


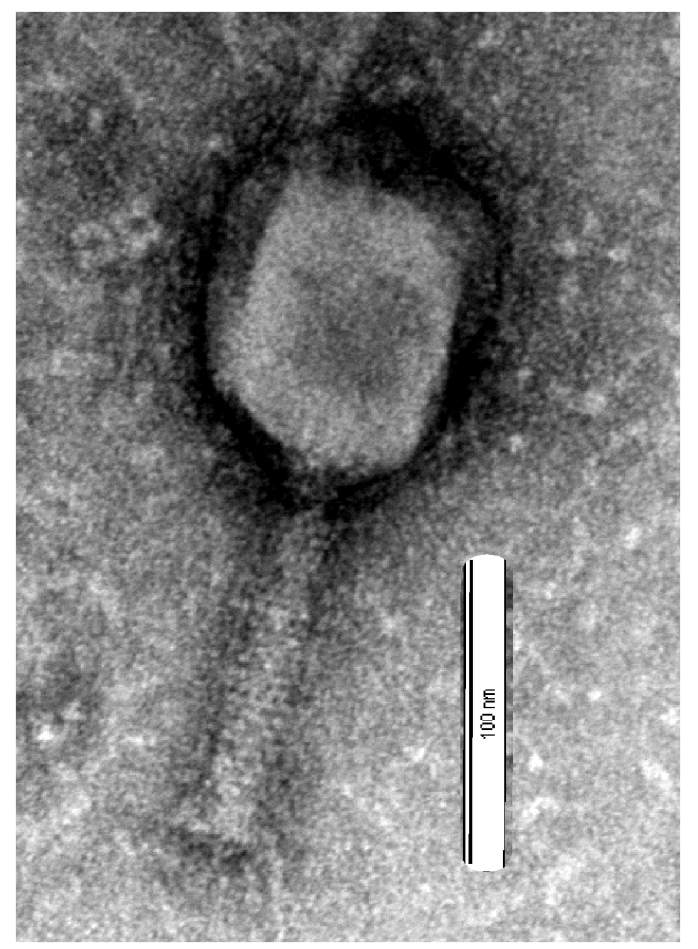

FIGURE 1 | Electron micrographs of phage $\boldsymbol{v} B \_$Ab-M-G7. Bar corresponds to $100 \mathrm{~nm}$.

PFGE showed that the phage DNA size was $90 \mathrm{~kb}$. None of the 8 (BamHI, EcoR I, EcoRV, HindIII, HincII, PstI, DpnI, SpeI) restriction endonucleases used in this study digested phage vB_Ab-M-G7, although they did digest the DNA of other phages.

\section{Phage Therapy in Infected Animal Wound Model}

All of the Group I animals survived and no A. baumannii strains were isolated (grown in Herellae agar) from the samples taken from them, indicating that the wound modeling was done in

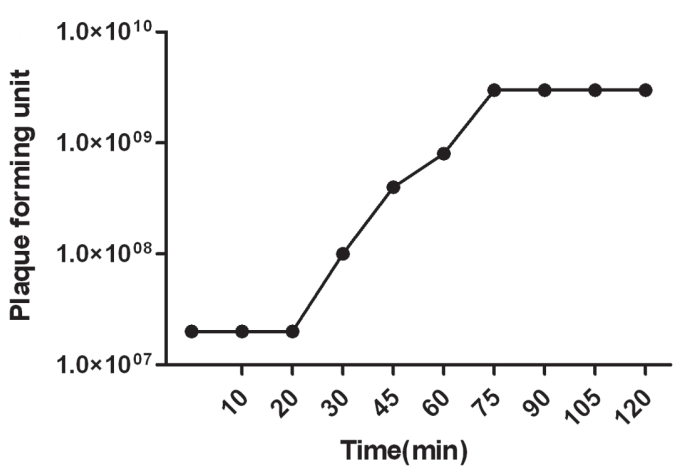

FIGURE 2 | Single step growth curve of phage $\boldsymbol{v} \boldsymbol{B} \_\boldsymbol{A} \boldsymbol{b}-\boldsymbol{M}-\mathbf{G} 7$. The latent phase takes average $20 \mathrm{~min}$ and the phage produces about $120 \mathrm{pfu} \mathrm{ml}^{-1}$ per infected cell.

sterile conditions and this artificial wound did not affect the rats' mortality.

To examine the toxicity of phage, the wounded but not infected experimental Group II was used, where only phage $v B$ $G E C \_A b-M-G 7$ was applied to the artificial wound. All of the wounded rats survived, indicating that phage phi G7 was not toxic. Samples taken from the animals showed no contamination with A. baumannii and the titer of the phage was not more than $2 \times 10^{1} \pm 1.7(\mathrm{SD}) \mathrm{pfu} \mathrm{m}^{-1}$ in each samples taken during the experiments (Table 1).

In groups III and $\mathrm{V}$, the animals were administered $1 \mathrm{ml}$ of A. baumannii T-10 or G7 $\left(5 \times 10^{8} \mathrm{cfu} \mathrm{ml}^{-1}\right)$. Purulent and inflammatory processes after the second day of infection could be easily observed and became heavier at the end of experiment, indicating of infection and not colonization. Wounds infected with A. baumannii G7 were observed to be more serious and complicated, and in group $\mathrm{V}$ the rate of mortality was $30 \%$, by the fifth day of the experiment. Microbial growth is shown in Figure 4 and Table 1. Samples were tested for phage contamination; no phage plaques were detected in the plated samples from animal groups III and V.
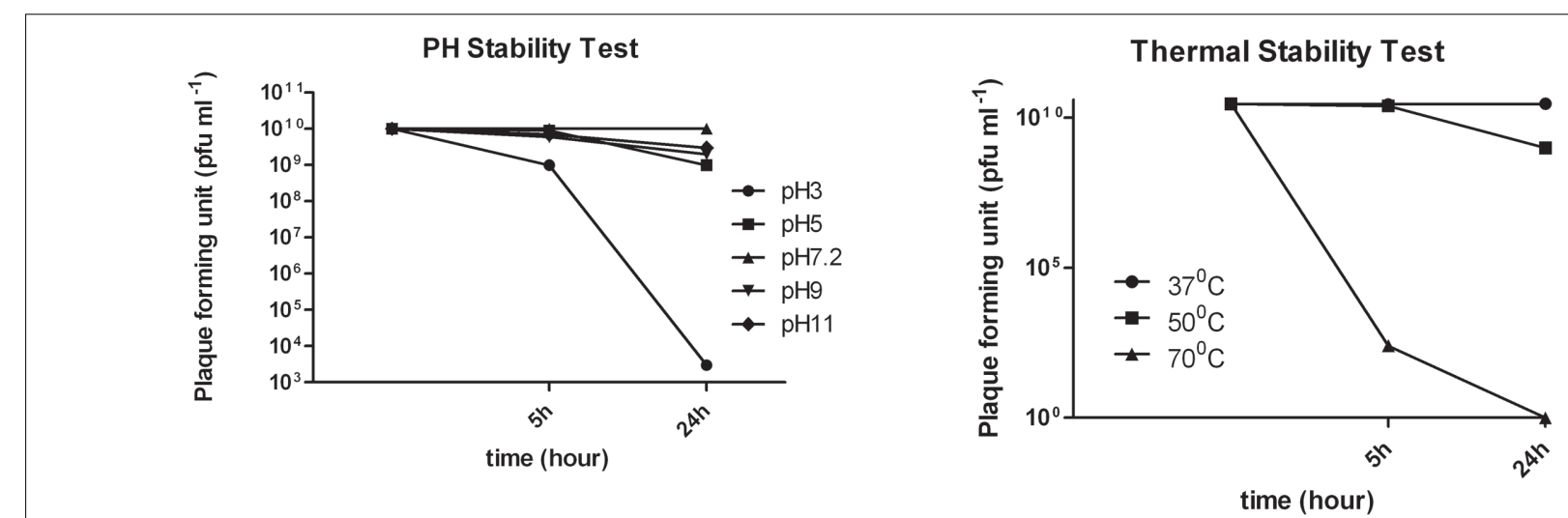

FIGURE 3 | pH and thermal stability of phage vB_Ab-M-G7. 
TABLE 1 | Alternation of the bacterial titer in phage treated infected wounds.

\begin{tabular}{|c|c|c|c|c|c|}
\hline Groups & Rats (200-300 g) & $\begin{array}{l}\text { Bacterial Infection } \\
\left(1 \mathrm{ml} 5 \times 10^{8} \mathrm{CFU}^{\prime \prime} \mathrm{ml}^{-1}\right)\end{array}$ & $\begin{array}{c}\text { Delay Before Phage } \\
\text { Application }\end{array}$ & $\begin{array}{l}\text { Phage Application } \\
1 \mathrm{ml} 5 \times 10^{7} \mathrm{PFU} \mathrm{ml}^{-1} \text { (6 days) }\end{array}$ & Results \\
\hline I & Aseptic wound & - & - & - & No strain was isolated \\
\hline ॥ & Aseptic wound & - & $12 \mathrm{~h}$ & Phi G7 & $\begin{array}{l}\text { No strain was isolated; } \\
2 \times 10^{1} \pm 1.7(\mathrm{SD})^{\prime} \text { PFU"' } \mathrm{ml}^{-1}\end{array}$ \\
\hline III & Infected wound & A. baumannii T10 & - & - & 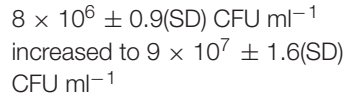 \\
\hline IV & Infected wound & A. baumannii T10 & $12 \mathrm{~h}$ & Phi G7 & $\begin{array}{l}7 \times 10^{6} \pm 0.9(\mathrm{SD}) \mathrm{CFU} \mathrm{ml}^{-1} \\
\text { decreased to } 9 \times 10^{2} \pm \\
1.3(\mathrm{SD}) \mathrm{CFU} \mathrm{m \textrm {ml } ^ { - 1 }}\end{array}$ \\
\hline V & Infected wound & A. baumannii G7 & - & - & $\begin{array}{l}1 \times 10^{7} \pm 1.8(\mathrm{SD}) \mathrm{CFU} \mathrm{ml}^{-1} \\
\text { increased to } 2,5 \times 10^{8} \pm \\
2.9(\mathrm{SD}) \mathrm{CFU} \mathrm{ml}\end{array}$ \\
\hline VI & Infected wound & A. baumannii G7 & $12 \mathrm{~h}$ & Phi G7 & $\begin{array}{l}1,4 \times 10^{7} \pm 0.9(\mathrm{SD}) \mathrm{CFU} \mathrm{ml}^{-1} \\
\text { decreased to } 3 \times 10^{2} \pm \\
1.9(\mathrm{SD}) \mathrm{CFU} \mathrm{ml} \mathrm{ml}^{-1}\end{array}$ \\
\hline
\end{tabular}

', Standard Deviation; ", Colony Forming Unit; "', Plaque Forming Unit.

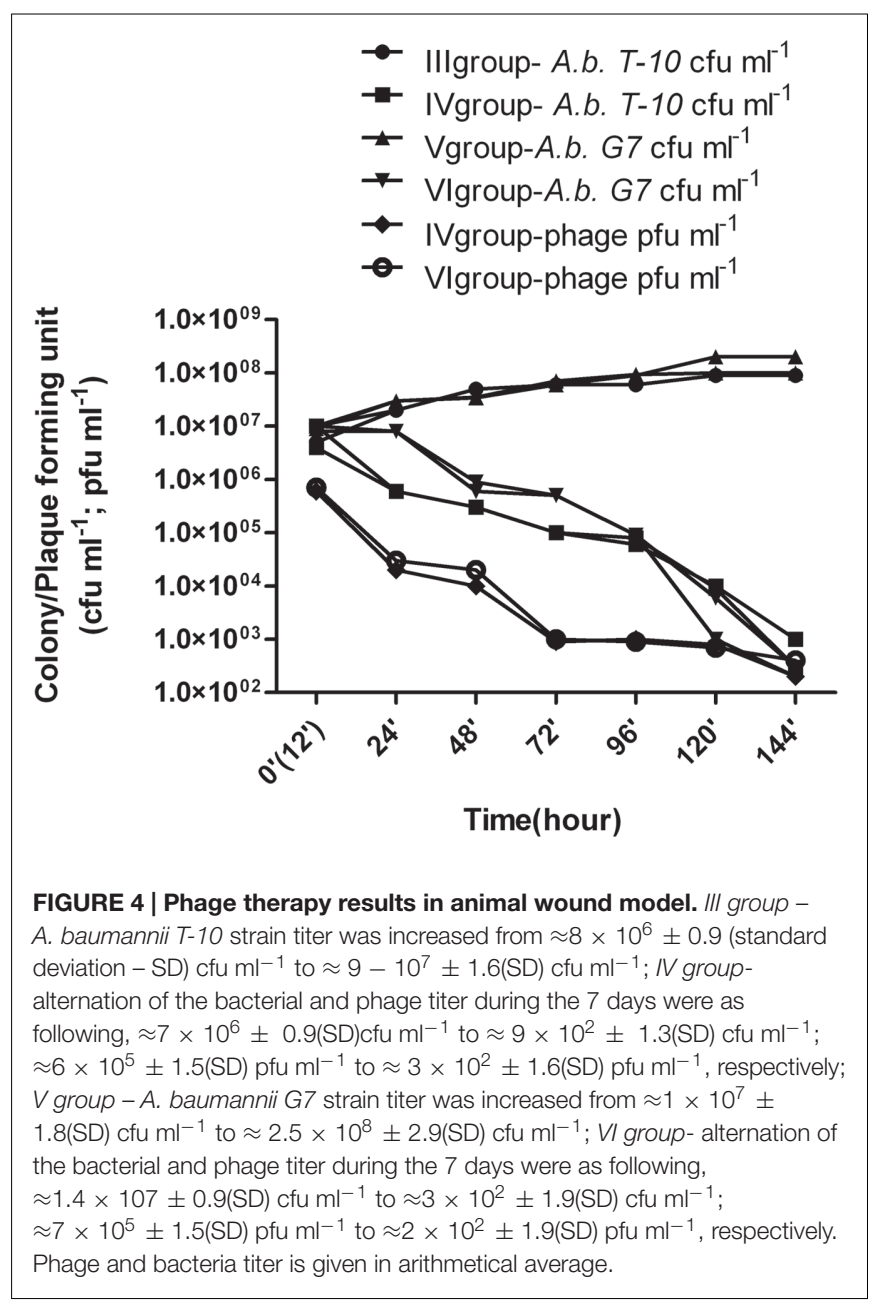

Group VI - $12 \mathrm{~h}$ after infection with $1 \mathrm{ml}$ of $A$. baumannii G7 $\left(5 \times 10^{8} \mathrm{cfu} \mathrm{ml}^{-1}\right), 1 \mathrm{ml}$ of $5 \times 10^{7} \mathrm{pfu} \mathrm{ml}^{-1}$ phage phi G7 was applied to the wound during 6 days. During treatment the rats were active and some of them were aggressive. Before the phage application no inflammatory processes were present. By the third, day purulent processes appeared which fully vanished by the end of the experiment. The reduction of the infection symptoms was correlated with decreasing of the bacteria titer to an average $3 \times 10^{2} \pm 1.9(\mathrm{SD}) \mathrm{cfu} \mathrm{ml}^{-1}$ and the phage titer dropped from $7 \times 10^{5} \pm 1.5(\mathrm{SD}) 2 \times 10^{2} \pm 1.9(\mathrm{SD}) \mathrm{pfu} \mathrm{ml}^{-1}$ (Figure 4, Table 1). All the animals survived.

Group IV -A. baumannii $T-10$ showed less virulence than A. baumannii G7, (groups III and V). Slight inflammations, as well as a little purulence were characteristics of the treatment processes, but it fully disappeared before days 5 and 6. Decreasing of the bacterial and phage titer, respectively, are given in Figure 4 and Table 1.

\section{DISCUSSION}

Due to the increase in the number of antibiotic resistant microbes, phage therapy is considered as alternative treatment for MDR bacterial infections (Chibani-Chennoufi et al., 2004; Sulakvelidze, 2005; Debarbieux et al., 2010; Kutter et al., 2010). Phage preparations are widely used to treat infections caused by E. coli, Pseudomonas aeruginosa, Salmonella spp., Enterococcus faecium, Streptococcus spp., Staphylococcus aureus and Proteus spp. in countries of the former Soviet Union (Matsuzaki et al., 2005; Sulakvelidze, 2005), but A. baumannii phages have not yet been used as therapeutic tools. In our study we have shown effectiveness of the phage $v B-G E C \_A b-M-G 7$ in vivo, correlated with its high in vitro activity.

Phage phi G7 is a tailed virus with $90 \mathrm{~kb}$ double stranded DNA genomes, belonging to the Myoviridae family. Some characteristics of phage phi G7 are: a short latent period and large burst size, quite wide host range $(68 \%$ on 200 clinical strains), resistant to chloroform and stabile in different thermal and $\mathrm{pH}$ ranges. Resistance to different restriction enzymes presumably helps make this phage active over such a wide 
spectrum; sequencing of the phage will determine whether this involves selection against all such restriction sites, as was observed for staph phage SB-1 (Kvachadze et al., 2011) or some other mechanism, such as the substitution of an unusual base seen in coliphage T4 and its relatives (Miller et al., 2003). All these characteristics help made phage phi G7 a very promising component of a cocktail for treatment of $A$. baumannii infection. For this in vivo study we selected two A. baumannii strains: $G 7$ and $T-10$ that were correctly identified as A. baumannii using MALDI-TOF MS. Patient-delivered A. baumannii G7 is the host for phage phi G7 and strain T-10 was chosen randomly from phi G7 sensitive strains for this experiment. No phage phi G7 adaptation procedures were carried out using the A. baumannii $T-10$ strain. We wanted to show the effectiveness of the phage phi $G 7$ therapy in an artificial infected rats wound model and at the same time to investigate potential differences in the therapeutic effectiveness of this phage, for treatment of infections caused by both host and randomly selected A. baumannii strains.

We have demonstrated in this animal wound model that the phage application did not have a toxic effect on wounded rats: in phage control group (group II) where phages were administered to the wound all the rats survived, they were feeling calm and no aggression was observed. Phage application in wound infections caused by A. baumannii T-10 and G7 effectively reduced the number of bacteria isolated from treated animals and all visible infection symptoms (red, swollen-purulent wound) disappeared (Figure 4, Table 1). Aggressive behavior of the infected rats fully vanished which was correlated with disappearing of infection symptoms. Rats with infections caused by the original host strain and by a randomly selected strain were treated with the same successful results. Obviously more detailed studies examining the effect of the phage dosage,

\section{REFERENCES}

Ahmed, S. S., Alp, E., Ulu-Kilic, A., Dinc, G., Aktas, Z., Ada, B., et al. (2016). Spread of carbapenem-resistant international clones of Acinetobacter baumannii in Turkey and Azerbaijan: a collaborative study. Eur. J. Clin. Microbiol. Infect. Dis. 35, 1463-1468. doi: 10.1007/s10096-016-2685-x

Biswas, B., Adhya, S., Washart, P., Paul, B., Trostel, A. N., Powell, B., et al. (2002). Bacteriophage therapy rescues mice bacteremic from a clinical isolate of vancomycin-resistant Enterococcus faecium. Infect. Immun. 70, 204-210. doi: 10.1128/IAI.70.1.204-210.2002

Bittar, F., Richet, H., Dubus, J. C., Reynaud-Gaubert, M., Stremler, N., Sarles, J., et al. (2008). Molecular detection of multiple emerging pathogens in sputa from cystic fibrosis patients. PLoS ONE 3:e2908. doi: 10.1371/journal.pone. 0002908

Chibani-Chennoufi, S., Sidoti, J., Bruttin, A., Kutter, E., Sarker, S., and Brussow, H. (2004). In vitro and in vivo bacteriolytic activities of Escherichia coli phages: implications for phage therapy. Antimicrob. Agents Chemother. 48, 2558-2569. doi: 10.1128/AAC.48.7.2558-2569.2004

Debarbieux, L., Leduc, D., Maura, D., Morello, E., Criscuolo, A., Grossi, O., et al. (2010). Bacteriophages can treat and prevent Pseudomonas aeruginosa lung infections. J. Infect. Dis. 201, 1096-1104. doi: 10.1086/651135

Drulis-Kawa, Z., Mackiewicz, P., Kesik-Szeloch, A., Maciaszczyk-Dziubinska, E., Weber-Dabrowska, B., Dorotkiewicz-Jach, A., et al. (2011). Isolation and characterisation of KP34-a novel phiKMV-like bacteriophage for Klebsiella pneumoniae. Appl. Microbiol. Biotechnol. 90, 1333-1345. doi: 10.1007/s00253011-3149-y timing of phage administration, pharmacokinetics will need to be undertaken before $A$. baumannii phages can be used in therapy. However, our characterization of phage $v B$-GEC_Ab-MG7and animal experimentation illustrates its big potential for treatment of infections. We hope this study will provide further insight on treating infections caused by MDR strains using phage administration.

\section{AUTHOR CONTRIBUTIONS}

IK planned given research and analysed obtained results. NK, SR, and TD were involved in phage research. IA and MK performed animal experiment. MG was consulting.

\section{FUNDING}

This work was funded in part by Eliava BioPreparations Ltd (Gotua str. 3, 0160 Tbilisi, Georgia).

\section{ACKNOWLEDGMENTS}

We are grateful to Professor Jean-marc Rolain (Unité de Recherche sur les Maladies Infectieuses et Tropicales Emergents (URMITE), Faculté de Médecine et de Pharmacie, Université de la Méditerranée Aix-Marseille II, 27 Bd Jean Moulin 13385 Marseille Cedex 05, France) for supporting and providing clinical A. baumannii strains and to Dr. Ekaterine Mitaishvili (Ivane Javakhishvili Tbilisi State University) for providing work with animals. We thank to Elisabeth Kutter for her help.

Garbe, J., Wesche, A., Bunk, B., Kazmierczak, M., Selezska, K., Rohde, C., et al. (2010). Characterization of JG024, a pseudomonas aeruginosa PB1-like broad host range phage under simulated infection conditions. BMC Microbiol. 10:301. doi: 10.1186/1471-2180-10-301

Gupta, M., Lakhina, K., Kamath, A., Vandana, K. E., Mukhopadhyay, C., Vidyasagar, S., et al. (2016). Colistin-resistant Acinetobacter baumannii ventilator-associated pneumonia in a tertiary care hospital: an evolving threat. J. Hosp. Infect. 94, 72-73. doi: 10.1016/j.jhin.2016.04.014

Jawad, A., Hawkey, P. M., Heritage, J., and Snelling, A. M. (1994). Description of leeds Acinetobacter medium, a new selective and differential medium for isolation of clinically important Acinetobacter spp., and comparison with Herellea agar and Holton's agar. J. Clin. Microbiol. 32, 2353-2358.

Jeon, J., Ryu, C. M., Lee, J. Y., Park, J. H., Yong, D., and Lee, K. (2016). In vivo application of bacteriophage as a potential therapeutic agent to control OXA-66-Like carbapenemase-producing Acinetobacter baumannii strains belonging to sequence type 357. Appl. Environ. Microbiol. 82, 4200-4208. doi: 10.1128/AEM.00526-16

Karumidze, N., Kusradze, I., Rigvava, S., Goderdzishvili, M., Rajakumar, K., and Alavidze, Z. (2013). Isolation and characterisation of lytic bacteriophages of Klebsiella pneumoniae and Klebsiella oxytoca. Curr. Microbiol. 66, 251-258. doi: 10.1007/s00284-012-0264-7

Kempf, M., and Rolain, J. M. (2012). Emergence of resistance to carbapenems in Acinetobacter baumannii in Europe: clinical impact and therapeutic options. Int. J. Antimicrob. Agents 39, 105-114. doi: 10.1016/j.ijantimicag.2011.10.004

Kropinski, A. M., Prangishvili, D., and Lavigne, R. (2009). Position paper: the creation of a rational scheme for the nomenclature of viruses of 
Bacteria and Archaea. Environ. Microbiol. 11, 2775-2777. doi: 10.1111/j.14622920.2009.01970.x

Kusradze, I., Diene, S. M., Goderdzishvili, M., and Rolain, J. M. (2011). Molecular detection of OXA carbapenemase genes in multidrug-resistant Acinetobacter baumannii isolates from Iraq and Georgia. Int. J. Antimicrob. Agents 38, 164-168. doi: 10.1016/j.ijantimicag.2011.03.021

Kutateladze, M., and Adamia, R. (2008). Phage therapy experience at the Eliava Institute. Med. Mal. Infect. 38, 426-430. doi: 10.1016/j.medmal.2008.06.023

Kutateladze, M., and Adamia, R. (2010). Bacteriophages as potential new therapeutics to replace or supplement antibiotics. Trends Biotechnol. 28, 591595. doi: 10.1016/j.tibtech.2010.08.001

Kutter, E., De, V. D., Gvasalia, G., Alavidze, Z., Gogokhia, L., Kuhl, S., et al. (2010). Phage therapy in clinical practice: treatment of human infections. Curr. Pharm. Biotechnol. 11, 69-86. doi: 10.2174/138920110790725401

Kvachadze, L., Balarjishvili, N., Meskhi, T., Tevdoradze, E., Skhirtladze, N., Pataridze, T., et al. (2011). Evaluation of lytic activity of staphylococcal bacteriophage Sb-1 against freshly isolated clinical pathogens. Microb. Biotechnol. 4, 643-650. doi: 10.1111/j.1751-7915.2011.00259.x

Lin, N. T., Chiou, P. Y., Chang, K. C., Chen, L. K., and Lai, M. J. (2010). Isolation and characterization of phi AB2: a novel bacteriophage of Acinetobacter baumannii. Res. Microbiol. 161, 308-314. doi: 10.1016/j.resmic.2010.03.007

Lopez-Rojas, R., Jimenez-Mejias, M. E., Lepe, J. A., and Pachon, J. (2011). Acinetobacter baumannii resistant to colistin alters its antibiotic resistance profile: a case report from Spain. J. Infect. Dis. 204, 1147-1148. doi: 10.1093/infdis/jir476

Matsuzaki, S., Rashel, M., Uchiyama, J., Sakurai, S., Ujihara, T., Kuroda, M., et al. (2005). Bacteriophage therapy: a revitalized therapy against bacterial infectious diseases. J. Infect. Chemother. 11, 211-219. doi: 10.1007/s10156-0050408-9

McVay, C. S., Velasquez, M., and Fralick, J. A. (2007). Phage therapy of Pseudomonas aeruginosa infection in a mouse burn wound model. Antimicrob. Agents Chemother. 51, 1934-1938. doi: 10.1128/AAC.01028-06

Michalopoulos, A. S., and Falagas, M. E. (2011). Colistin: recent data on pharmacodynamics properties and clinical efficacy in critically ill patients. Ann. Intensive Care 1, 30. doi: 10.1186/2110-5820-1-30

Miller, E. S., Kutter, E., Mosig, G., Arisaka, F., Kunisawa, T., and Ruger, W. (2003). Bacteriophage T4 genome. Microbiol. Mol. Biol. Rev. 67, 86-156. doi: 10.1128/MMBR.67.1.86-156.2003

Montero, A., Ariza, J., Corbella, X., Domenech, A., Cabellos, C., Ayats, J., et al. (2004). Antibiotic combinations for serious infections caused by carbapenemresistant Acinetobacter baumannii in a mouse pneumonia model. J. Antimicrob. Chemother. 54, 1085-1091. doi: 10.1093/jac/dkh485

Morello, E., Saussereau, E., Maura, D., Huerre, M., Touqui, L., and Debarbieux, L. (2011). Pulmonary bacteriophage therapy on Pseudomonas aeruginosa cystic fibrosis strains: first steps towards treatment and prevention. PLoS ONE 6:e16963. doi: 10.1371/journal.pone.0016963

Nowak, P., and Paluchowska, P. (2016). Acinetobacter baumannii: biology and drug resistance - role of carbapenemases. Folia Histochem. Cytobiol. doi: 10.5603/FHC.a2016.0009 [Epub ahead of print].
Popova, A. V., Zhilenkov, E. L., Myakinina, V. P., Krasilnikova, V. M., and Volozhantsev, N. V. (2012). Isolation and characterization of wide host range lytic bacteriophage AP22 infecting Acinetobacter baumannii. FEMS Microbiol. Lett. 332, 40-46. doi: 10.1111/j.1574-6968.2012.02573.x

Rigvava, S., Tchgkonia, I., Jgenti, D., Dvalidze, T., Carpino, J., and Goderdzishvili, M. (2013). Comparative analysis of the biological and physical properties of Enterococcus faecalis bacteriophage vB_EfaS_GEC-EfS_3 and Streptococcus mitis bacteriophage vB_SmM_GEC-SmitisM_2. Can. J. Microbiol. 59, 18-21. doi: 10.1139/cjm-2012-0385

Seng, P., Drancourt, M., Gouriet, F., La, S. B., Fournier, P. E., Rolain, J. M., et al. (2009). Ongoing revolution in bacteriology: routine identification of bacteria by matrix-assisted laser desorption ionization time-of-flight mass spectrometry. Clin. Infect. Dis. 49, 543-551. doi: 10.1086/600885

Shivaswamy, V. C., Kalasuramath, S. B., Sadanand, C. K., Basavaraju, A. K., Ginnavaram, V., Bille, S., et al. (2015). Ability of bacteriophage in resolving wound infection caused by multidrug-resistant Acinetobacter baumannii in uncontrolled diabetic rats. Microb. Drug Resist. 21, 171-177. doi: $10.1089 / \mathrm{mdr} .2014 .0120$

Soothill, J. S. (1992). Treatment of experimental infections of mice with bacteriophages. J. Med. Microbiol. 37, 258-261. doi: 10.1099/00222615-37-4258

Sulakvelidze, A. (2005). Phage therapy: an attractive option for dealing with antibiotic-resistant bacterial infections. Drug Discov. Today 10, 807-809. doi: 10.1016/S1359-6446(05)03441-0

Vinodkumar, C. S., Neelagund, Y. F., and Kalsurmath, S. (2005). Bacteriophage in the treatment of experimental septicemic mice from a clinical isolate of multidrug resistant Klebsiella pneumoniae. J. Commun. Dis. 37, 18-29.

Wang, Y., Mi, Z., Niu, W., An, X., Yuan, X., Liu, H., et al. (2016). Intranasal treatment with bacteriophage rescues mice from Acinetobacter baumanniimediated pneumonia. Future Microbiol. 11, 631-641. doi: 10.2217/fmb.16.11

Yang, H., Liang, L., Lin, S., and Jia, S. (2010). Isolation and characterization of a virulent bacteriophage AB1 of Acinetobacter baumannii. BMC Microbiol. 10:131. doi: 10.1186/1471-2180-10-131

Yilmaz, G. R., Dizbay, M., Guven, T., Pullukcu, H., Tasbakan, M., Guzel, O. T., et al. (2016). Risk factors for infection with colistin-resistant gram-negative microorganisms: a multicenter study. Ann. Saudi Med. 36, 216-222. doi: $10.5144 / 0256-4947.2016 .216$

Conflict of Interest Statement: The authors declare that the research was conducted in the absence of any commercial or financial relationships that could be construed as a potential conflict of interest.

Copyright (c) 2016 Kusradze, Karumidze, Rigvava, Dvalidze, Katsitadze, Amiranashvili and Goderdzishvili. This is an open-access article distributed under the terms of the Creative Commons Attribution License (CC BY). The use, distribution or reproduction in other forums is permitted, provided the original author(s) or licensor are credited and that the original publication in this journal is cited, in accordance with accepted academic practice. No use, distribution or reproduction is permitted which does not comply with these terms. 